\title{
THEORY OF REASONED ACTION FOR CONTINUOUS IMPROVEMENT CAPABILITIES: A BEHAVIORAL APPROACH
}

\author{
TEORIA DA AÇÃO RACIONAL NA COMPETÊNCIA DE MELHORIA CONTÍNUA: ABORDAGEM \\ COMPORTAMENTAL
}

TEORÍA DE LA ACCIÓN RACIONAL EN LA COMPETENCIA DE MEJORÍA CONTINUA: ABORDAJE COMPORTAMENTAL

\section{ABSTRACT}

The importance of interaction between Operations Management (OM) and Human Behavior has been recently re-addressed. This paper introduced the Reasoned Action Theory suggested by Froehle and Roth (2004) to analyze Operational Capabilities exploring the suitability of this model in the context of OM. It also seeks to discuss the behavioral aspects of operational capabilities from the perspective of organizational routines. This theory was operationalized using Fishbein and Ajzen (F/A) behavioral model and a multi-case strategy was employed to analyze the Continuous Improvement (CI) capability. The results posit that the model explains partially the CI behavior in an operational context and some contingency variables might influence the general relations among the variables involved in the F/A model. Thus intention might not be the determinant variable of behavior in this context.

keywords Behavioral operations, continuous improvement, operational capability, Fishbein and Ajzen’s behavioral model, organizational routines.

Chen Yen-Tsang yentsang@gvmail.br

Ph.D Student in Business Administration, Escola de Administração de Empresas de São Paulo, Fundação Getulio Vargas - São Paulo - SP, Brazil

João Mário Csillag joao.mario.csillag@fgv.br

Professor at Escola de Administração de Empresas de São Paulo, Fundação Getulio Vargas - São Paulo - SP, Brazil

Janaina Siegler janaina.siegler@gmail.com

Ph.D Student in Business Administration, Escola de Administração de Empresas de São Paulo, Fundação Getulio Vargas - São

Paulo - SP, Brazil

Resumo A importância da interação entre as áreas de operações e gestão de pessoas tem sido recentemente ressaltada. Este trabalho adotou a teoria da Ação Racional sugerida por Froelhe and Roth (2004) para analisar as competências operacionais, objetivando explorar a adequação deste modelo no contexto de gestão de operações, e o aspecto comportamental das capacidades operacionais sob a perspectiva de rotinas organizacionais. A teoria foi operacionalizada utilizando o modelo comportamental de Fishbein e Ajzen (F/A) e analisada a competência de Melhoria Contínua. Metodologicamente, foi empregada estratégia multicasos com casos representativos. Os resultados indicam que este modelo explica parcialmente 0 comportamento da Melhoria Contínua e algumas variáveis contingenciais podem influenciar a relação geral entre as variáveis envolvidas no modelo F/A, assim, intenção pode não ser a variável determinante do comportamento nesse contexto. Palavras-chave Comportamento em operações, melhoria contínua, capability operacional, modelo comportamental de Fishbein e Ajzen, rotinas organizacionais.

Resumen La importancia de la interacción entre las áreas de gestión de operaciones y gestión de personas ha sido resaltada recientemente por diversos autore. Este trabajo adoptó la teoría de la Acción Racional sugerida por Froelhe and Roth (2004) para analizar las competencias operacionales, a los efectos de explorar la adecuación de este modelo en el contexto de gestión de operaciones, así como de explorar el aspecto comportamental de las capacidades operacionales desde la perspectiva de rutinas organizacionales. La teoría fue operacionalizada utilizando el modelo de comportamiento de Fishbein y Ajzen (F/A) y la competencia analizada fue la de Mejoría Continua. Metodológicamente, se empleó una estrategia multicasos con casos representativos. Como resultado, el presente estudio postula que, en el contexto de gestión de operaciones, este modelo explica parcialmente el comportamiento de la Mejoría Continua y algunas variables contingenciales pueden influenciar la relación general entre las variables involucradas en el modelo F/A, así, la intención puede no ser la variable determinante del comportamiento en ese contexto.

Palabras clave Comportamiento en Operaciones, Mejoría Continua, Capability Operacional, Modelo comportamental de Fishbein y Ajzen, rutinas organizativas 


\section{INTRODUCTION}

Continuous improvement (CI) is a key feature in maintaining the competitiveness of a company in the current global scenario of a borderless world (IMAI, 1997; PRADO, 1997; PENG and others, 2008). As argued by Imai (1986) and Isobe and others (2008), disruptive innovations alone are not enough to keep a company competitive over a period of time.

In view of the importance of CI for companies, for some time, several studies have investigated the necessary requirements for the successful implementation of a continuous improvement program (BESSANT and others, 2001; BESSANT \& FRANCIS, 1999; SAVOLAINEN, 1999; SCHROEDER and ROBINSON, 1991) and almost all these studies have found that the involvement of employees is one of the most important factors in ensuring its success.

Existing research often tends to link the question of employee involvement to that of leadership (ANAND and others, 2009; SAVOLAINEN, 1999; PENG and others, 2008); however, BESSANT and others (1994) have revealed that this issue is much more complex than appears at first sight and is also determined by contextual and behavioral factors.

Despite the findings of Bessant and others (1994), during the 1980s and 90s, research into CI focused on prescriptive processes and quality programs (JHA and others, 1996). These processes and programs were regarded as tools or measures to improve the performance of the organization.

However, this trend followed by researchers in the 1980s and 90s, changed when a conceptual foundation was introduced by the resource based view (RBV) (PETERAF and BARNEY, 2003; WERNERFELT, 1984). At the same time, new light was shed on the CI phenomenon and the importance of the human aspects of the prescriptive Operational programs, was brought back to the discussion (POWELL, 1995, AHMAD and SCHROEDER, 2003; SILA, 2007; MENEZES and others, 2010). Gino and Pisano (2008) and Bendoly and others, (2006) have supported this view by demonstrating that the way operating systems work, perform and respond to management interventions is significantly influenced by people; thus it became necessary to incorporate social, cognitive and psychological theories in Operations Management Research.

Given the strategic importance of CI, as well as the need for an exploration of this subject through a behavioral theoretical lens, this study introduces the theory of reasoned action (FISHBEIN AND AJZEN, 1975; FISHBEIN, 2000) to investigate the antecedents and behavioral ingredients that are required to ensure continuous improvement capability based on operational routines. The chosen scenario was companies in Brazil.

\section{THEORETICAL BACKGROUND}

The competitiveness of the Japanese companies during the 1980s and early 90s attracted attention because of their quality and production methodologies, such as Total Quality Management, Lean Manufacturing and 5S (JHA and others, 1996). These features, together with the Kaizen ideology, have been exhaustively studied and disseminated around the world (POWELL, 1995; RAHMAN, 2004); however, not all the companies that have implemented them, have obtained the same results as their Eastern competitors (PAY, 2008; POWELL, 1995).

\section{Continuous improvement capability}

As a result of several studies in the 1990s, (BERGER, 1997; BESSANT and others, 1994; CAFFYN, 1999; CHOI, 1995; SAVOLAINEN, 1999), it was found that a successful CI program should be driven and managed strategically and aligned with long- term and clearly defined organizational targets. In addition, it should be managed as a company-wide process that is supported by a proper infrastructure and toolkit; it should also be embedded in a culture that encourages constant change and employee involvement.

At the same time, until the mid-1990s, the mainstream of CI studies in the field, was focused on its procedures and toolkit factors, especially those related to quality management (JHA and others, 1996); during the second half of the 1990s, due to the influence of the resource based view (RBV), researchers adopted sustained CI initiatives as a capability of the company (BESSANT and FRANCIS, 1999; SAVOLAINEN, 1999) and became more concerned with the managerial and behavioral aspects of CI.

By applying the RBV, a capability of a firm can be defined as a combination of competences, skills and abilities that coordinate a set of tasks to achieve a particular goal or result, through organizational resources. The tasks involved comprise organizational 
routines that are associated with the managerial and operational day-to-day activities of a firm (PENG and others. 2008; TEECE and others, 1997).

On the basis of the above definition, CI can be viewed as a firm capability that seeks to achieve a particular organizational goal, which could be the improvement of organizational performance such as cost, delivery, quality, or any other indicators. Before this purpose can be attained, CI activities must be coordinated and based on a set of tasks deployed by the organizational resources. The result of the CI capability should not be ad-hoc, but recurrent and purposeful (ANAND and others, 2009).

\section{Behavioral aspects of continuous improvement capability}

According to Schroeder and Robinson (1991) the scientific management paradigm is based on the division of labor, standardization, control and mass production. It also distinguishes between the thinking labor force and those that "execute", and this segregation represents a drawback since it does not allow the organization to fully explore all of its opportunities to increase productive efficiency.

Barney (1991) argues that people can be considered to be the most important asset of an organization, and probably offer the key to generate new knowledge and thus provide the firm with a competitive advantage but very few organizations are able to fully harness this valuable resource (AHMAD, 2003; JENSEN and VINDING, 2003). The resource-based view suggests that it is difficult to draw on the tacit knowledge of people in a specific firm because of its attributes such as social complexity, specificity, path dependence and ambiguity (RUSSELL, 1997; AHMAD and SCHROEDER, 2003).

When these concepts are applied, CI capability can be regarded as a company-wide process based on a bundle of established operational routines, and its success depends on believing in the value of "small-step" incremental and innovative mindsets. Reintroducing the operational workers into the "thinking" process requires a deep change of shared beliefs and values and everyone in the organization must believe that he has the potential to contribute creative ideas (BESSANT and others, 2001; 1994).

\section{Capability in Fishbein's integrated model}

Initially, Fishbein and Ajzen (1975) proposed a fra- mework to explain behavior and its antecedents based on beliefs, attitudes and intentions (B-A-I) which is called the F/A model and postulates the existence of mechanisms that underlie individual behavioral changes (Strasser and others., 2009). The F/A model is among several other behavioral intention models used by researchers in many scientific fields such as Health, Communication, Marketing and Psychology in a wide range of different contexts and countries (CHAN and LAU, 1998; DAVIS, 1985; FROEHLE and ROTH, 2004; JO and others, 2003; LI and others, 2009; SCHWENK AND MÖSER, 2009; STRASSER and others, 2009). As a result, different studies have advocated good cross- cultural generalizations (LI and others, 2009; SCHWENK and MÖSER, 2009).

Fishbein and Middlestadt (1995) and Fishbein (2000) stated that any given behavior can be predicted by the intention to perform it. According to this model, skills, environmental constraints and intention to perform a behavior, are antecedents of behavior. This intention is a value of three determinants - the person's attitude toward performing the behavior, the person's perception of the social (or normative) pressure exerted on him or her to perform the behavior, and the person's belief in his or her ability to perform the behavior (self-efficacy).

The F/A model is based on the assumption that a person behaves, pro-actively depending on his willingness and intention (SCHWENK and MÖSER, 2009), thus, by analogy, the CI behavior in an organization should initially be based on the intention of how the company would like to perform the improvements. This link is perfectly logical, once according to Bessant and others (1994) and Bessant and Francis (1999), the CI should be conceived and planned strategically for the long term in accordance with the aims of the top management. Hence, it can be assumed that the CI behavior depends on the intention of how top managers would like to improve the company's procedures, products, activities or business strategies.

When the CI capability is combined with the F/A model, this capability should first be defined as a set of routines, as stated by Peng and others (2008); second, as Bessant and Francis (1999) argued, since routines and processes are the way people do things in a company, they can be assumed to be a kind of operational behavior which reflects human beliefs, values and attitudes (FISHBEIN, 2000; FISHBEIN and AJZEN, 1975). On the basis of these two assumptions, 
CI routines are preceded by CI behavior, which is predicted by the intention to perform it.

The CI intention can be influenced by attitudes toward the learning process (ANAND, and others, 2009; NI and SUN, 2009), leadership commitment and the involvement of employees in the quality processes (PENG, and others, 2008). From a normative perspective, factors such as the charges imposed by customers, legislation, competitive forces, and market demand (ADLER and others, 2009; BENNER and TUSHMAN, 2003), represent the obligations that result from the intention of the company to make improvements (see Figure 1).

With regard to self-efficacy, the CI behavior should, at a collective level, be characterized by activities aimed at improvement, such as 8D programs or FEMEA and, at an individual level, by attitudes that show how employees look forward to making improvements, such as self-engagement, new ideas, suggestions, a willingness to learn or a willingness to participate in team work (ANAND, and others, 2009; BESSANT, and others, 1994; SAVOLAINEN, 1999).

Finally, according to the F/A model, attitudes, norms and self-efficacy are influenced by subjective beliefs. Within the CI capability, it can be assumed that everyone in the company can offer small and creative ideas that can improve the local performance slightly and that the cumulative contribution of these small ideas can result a significant improvement in the performance of the company (BESSANT, and others, 2001; BESSANT, and others, 1994; SCHROEDER and ROBINSON, 1991).

This represents a common belief that the following requirements are necessary for a company: it should be provided with team work, a culture that does not blame employees for mistakes, a willingness to learn, a willingness to improve, commitment, freedom, openness to discussion and questioning, a belief in long- term planning, clearly defined strategic goals, etc (BESSANT, and others, 1994; SAVOLAINEN, 1999).

In summary, the CI capability, as defined in Fishbein's model, suggests the following three propositions should be investigated:

P1: CI behavior is preceded by the intention to perform it;

P2: Attitude, norm and self-efficacy define the intention to perform continuous improvement;

P3: Subjective beliefs underlie each of the attitudes, norms and examples of self-efficacy.

\section{Figure 1 - $\mathrm{Cl}$ capability under F/A model}

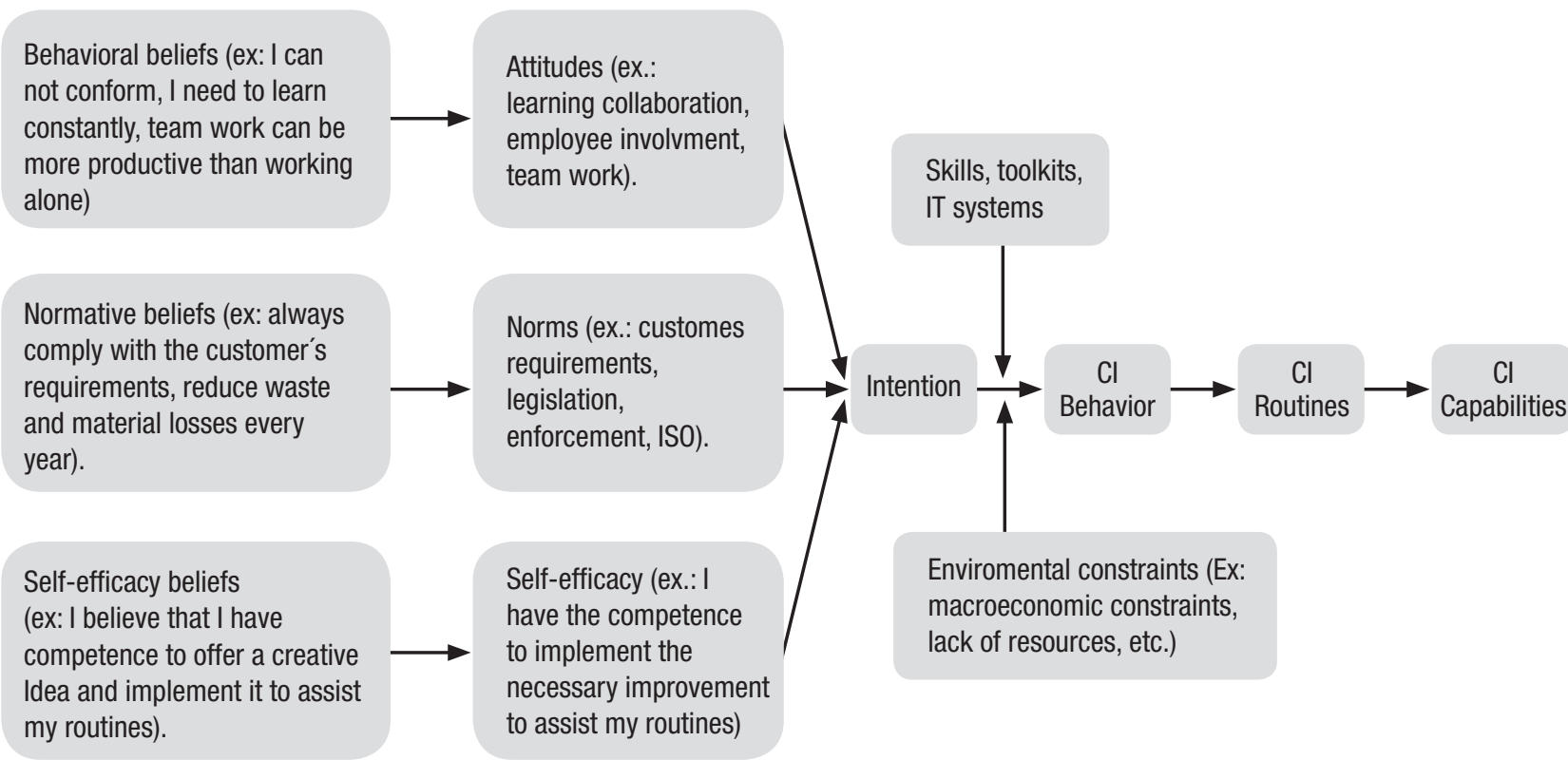




\section{RESEARCH DESIGN AND METHODS}

According to some authors (EISENHARDT, 1989; MEREDITH, 1998; SEURING, 1998), making the right choice is vital to the success of case studies. Voss and others (2002) lay down certain criteria for selecting the cases and following these guidelines, two conditions have been imposed for the present study:

a) The company must be well known for its continuous improvement capability;

b) The companies have demonstrated some sort of continuous improvement initiatives, although these may not necessarily have been fully developed.

The selection of the cases was also governed by criteria based on the combination of three sets of evidence over the last three years: (i) consistent growth in revenue; (ii) continuous improvement in the offered product or services; (iii) continuous improvement in the internal process.

The study was conducted in Brazil and, initially, to define the pool of candidates, the secondary data were consulted to satisfy the first and second criteria and consisted of Brazilian magazines (Exame Magazine "Best and Biggest 2009/2010, Great place to work '2009, Brazilian metallurgical industry - statistical yearbook 2009/2010), journals or national conferences (including anecdotal cases and conferences such as SIMPOI and EnAnpad). In the preliminary phase, there were eleven potential companies from various industries and all them were either benchmarks for their respective industries, representative cases of the studied phenom- enon, or winners of management awards that had been mentioned in journals and magazines and involved in some sort of continuous improvement.

All these candidates were contacted by phone and there remained six companies where the researchers paid a preliminary technical visit, conducted interviews and explained their initial commitments. In this later stage, the third criterion was verified to define the final cases. Three out of these six companies, were chosen as the cases to be analyzed by the research.

\section{Sample}

The companies that remained in the sample were designated as Company A, B and C, and each provided evidence of $\mathrm{CI}$ in their respective industries over the past three years. A brief overview of these companies can be found in Table 1 .

Company A demonstrated the way it adopted continuous improvement in 2008 and 2009, by re-launching its portfolio of products and making several incremental improvements - for example, introducing software with a more efficient use of computing resources, customer service with an adjustment of internal procedures, and a hardware product which increased the availability of controlled vehicle fleets. The company also improved its internal procedures concerning project configurations and version management, and thus has recently raised the level of customer satisfaction.

Company B provided evidence of continuous improvement by constantly simplifying the internal procedures adopted by the employees. These included the following: the elimination of jobs on the assembly line by installing intermediate buffers, increasing production

\section{Table 1 - Profiles of studied companies}

\begin{tabular}{|l|c|c|c|}
\hline & Company A & Company B & Company C \\
\hline Industry & Transport infrastructure & Metallurgic & Foundry \\
\hline City (localization) & São Paulo & São Paulo & Guarulhos \\
\hline No. of Employees & 600 & 900 & 500 \\
\hline Annual revenues (in millions of U\$) & $>240$ & $>240$ & Automakers and their suppliers \\
\hline Main customers & Miners, logistic providers; & Food and paints industries & medium \\
\hline Level of product customization & governt & low & migh \\
\hline Type of process & Project management & Serial production & low and medium volume lots \\
\hline
\end{tabular}


by giving a supporting role to the lithography machine, improving the quality of the working environment by installing an exhaust fan to remove the smell of solvents, and adopting procedures to reuse raw materials, among others. In addition to procedural improvements, CI in company B also generated disruptive innovations in products derived from various international patterns.

Company C's CI has mainly focused on the quality improvement. Over the past few years, it has planned and achieved a systematic reduction of $10 \%$ in internal waste. The year 2008 was an exception, as the Company faced problems with raw material coming from various countries of the world (such as China, South Africa and Poland), the performance did not match the established target. However, this problem provided an opportunity for the company to improve its internal procedure and make an improvement that was above the forecast for production waste of 2009.

\section{Data collection and analysis}

The data were collected mainly through semi-structured interviews conducted by the researchers in loco with the three participating companies. The interview questions were based on those recommended in the existing literature and semi-structured questionnaires were employed with a free-flowing discussion of topics in no particular order, although the researchers covered each question in the list. During the interviews, the researchers encouraged the interviewees to discuss the issues or examples they considered to be relevant to their work routines.

The sample of interviewees in each company consisted of an operational director, a plant/production manager, three to four operational level employees (an engineer, machine operator, systems analyst, etc.). These interviews lasted from forty-five minutes to an hour and a half; they were recorded and then later transcribed for analysis. To proceed with triangulation, unstructured technical visits were paid and these lasted from half a day up to two days. In this period, several other operational level employees were interviewed; however, these interviews could not be recorded.

All the transcribed interviews were analyzed by means of content analysis techniques (KRIPPENDORF, 2004; MILES AND HUBERMAN, 1994). The codification was carried out according to the constructs of the F/A model; afterwards, the frequencies of each construct were counted. When proceeding with the codification and data analysis, the researchers adopted the QDA
Miner qualitative research support application to organize and compile the data. As recommended by Mattos (2010), the authors took special care when choosing the software and deciding which kind of behavior should be codified.

According to Krippendorf (2004), one section of an interview or analyzed text can be coded into different categories, and this co-occurrence could not be avoided by the researchers. However, this phenomenon had to be explored since it is evidence of a logical relation between co-occurred constructs. Following Krippendorf's suggestion, this research has adopted the co-occurrence of the construct as evidence of the association and employed the Jaccard similarity coefficient to define the logical proximity between the co-occurred constructs. This coefficient is calculated from a fourfold table as $a /(a+b+c)$, where $a$ represents cases where both items occur, and $b$ and $c$ represent cases where one item is found but not the other. It is worth remembering that the coefficients must be compared with those from the same cases, ranging from 0 to 1 , where 0 means no similarity and 1 is the maximum similarity.

Triangulation was carried out by the researchers when collecting and analyzing the data to ensure internal validity and reliability and avoid the inherent risks of content analysis (SEURING, 2008; LEWIS, 1998). According to Eisenhardt (1989) the shaping hypothesis stage to see evidence for the "why" behind the relationships, is a means of helping to build internal validity,

\section{RESULTS AND DISCUSSIONS}

\section{Company A}

Company A is a part of a European multinational and one of the world leaders in the transport infrastructure sector with $18 \%$ of the market share in 2009 . It has operated in Brazil since 1985 through local companies that were subsequently incorporated.

Company A has demonstrated its ability to apply $\mathrm{CI}$ in a systematic way in its products and procedures since the beginning of its local operations in the 1980s. The products that are offered to the customer have constantly improved owing to the use of computer resources, functionality, security, and system availability and transport optimization. For example, in the 1980s, one of its products employed the LED panel to track the mass transport vehicles. During the 1990s, this company started to replace the LED panels with electronic 
displays and at the end of 90s, the electronic displays were replaced with rear projectors and it currently offers LCD panels to display vehicle locations. At the same time, several features of its products have also been improved, such as energy consumption control, leadtime schedules for the vehicles, passenger information system, and telecommunications system. Some CI has made possible disruptive innovations; for instance, the onboard vehicle safety measures gave rise to the driverless system.

In carrying out continuous improvements, the policy of this company was that those that required greater funding should be conducted by the R\&D departments spread around the world (which received 104 million Euros in 2009/2010), while those requiring a small financial investment were conducted by the project managers, for example replacing the control panel technology or improving the system functionality.

These small improvements are usually suggested by the participants of the projects and then put into effect by the project managers either at formal meetings or informally. According to a project director, the project manager evaluates these ideas and if they are strategically aligned with the company philosophy, then they are implemented. The decision drivers are cost, quality and delivery.

At company $\mathrm{A}$, the employees are involved in the CI initiatives through problem solving schemes inside each project that is implemented and supported by intensive teamwork. However, its success still largely depends on the motivation of the project manager since the employees are not involved in the CI programs outside of the projects.

\section{Company B - Representative case for this study}

Company B is a medium- sized Brazilian company that produces metallic cans for painting, food and beverage industries. Its products can be considered to be commodities where it is difficult to make innovations and improvements.

The CI capability in Company B has brought it widespread recognition such as 11 awards in 15 editions of Best packing supplier, and 21 awards in 22 editions of the supplier of the year by Syndicate of Paint and Varnish Industry of the State of Sao Paulo. Since 1999 its products have constantly featured in the top three positions of the national and international "Cans of the year award".
The continuous improvements in Company $\mathrm{B}$ can be attributed to ideas suggested by the employees. This specific CI program encourages employees to suggest ideas individually as well as collectively and the decision about whether to approve and implement them is generally made by the front line employee.

To make this program works, Company B relies on its participative philosophy and long-term relationship with the employees. All the employees share a common belief that everyone can contribute by offering small ideas, which cumulatively, can lead to significant results for the company.

In 2009, there were approximately 170 thousand ideas suggested by almost 900 employees and more that $90 \%$ of them were implemented. As a manager pointed out, these ideas need not be brilliant, since the objective of the scheme is to create an environment that motivates communication, experimentation, dialogue and inquiry, and stimulates creativity.

\section{Company C}

Case $\mathrm{C}$ is a company that provides small and medium-sized technical parts for the heavy automotive market, i.e., trucks tractors, buses and engines and transmissions manufactures.

This company has clearly adopted a quality orientation. In addition to the ISO/TS 16949:2009 and ISO 14000 , there is a specific quality campaign for continuous improvement and deployment of several crossfunctional quality process tools such as $5 \mathrm{~S}, 5 \mathrm{H} 1 \mathrm{~W}, 8 \mathrm{D}$, MSA and statistical controls.

As evidence of continuous improvement, in 2009, it adjusted the process to handle raw materials by implementing a quality control while they were still on the trucks. This new procedure was proposed by a cross-functional problem- solving team that was set up to reduce internal waste, increase product quality and improve production efficiency.

This company is provided with two employee involvement schemes and a quality campaign so that it can maintain its continuous improvement. The incentive for carrying out the employee involvement campaign is a monetary prize when the internal waste target is achieved at the end of each year. This indicator establishes a $10 \%$ reduction in internal waste each year and the employees must find a way to achieve it. They can either work individually or in groups or participate in a problem- solving team. 
The employees are given support to achieve this target through formal weekly meetings held by each team leader and several informal meetings to discuss any problem or opportunity for expansion. As one supervisor stated, $50 \%$ of the solutions can be attributed to the operational employees and 50\% to the problemsolving team.

With regard to the employee involvement scheme, in formal terms, there is a "continuous improvement team" and an idea suggestion system. Whereas the CI team is a cross-functional group whose purpose is to detect potential improvements in the company, the idea system seeks to draw on the contributions made by the individual employees.

Despite being designed to improve organizational performance, the idea system also welcomes suggestions to improve the working environment, since the temperature inside the factory is extremely hot (around $108^{\circ} \mathrm{F}$ ), and the conditions dusty, hazardous and uncongenial. Given this environment, all the tasks require a high degree of attention and are physically demanding, and thus, there is a high turnover of employees.

\section{Empirical evidence}

The results of the codification (Table 2) show that attitude toward the $\mathrm{CI}$ intention is most frequent among the coded constructs (203 citings) and the second is the norms toward the intention (171 citings). While proceeding with the codification, the continuous improvement behavior was viewed as the dependent variable that had to be observed.

\section{Company A}

On the evidence of the interviews, at Company A continuous improvement is mandatory. CI is very often a requirement imposed by the customer and the problems are solved through the standards and procedures laid down by the project management to comply with the orders "... When our customer does not feel comfortable (with the performance) or does not agree, the whole team come and sit together (for a solution)". Taking these factors into consideration, the normative motivations seem to be the driving-force behind the CI behavior. The way it improves depends on the amount of investment in the R\&D of their products and toolkits by the project management.

After the interviews of Company A were coded, it could be noted, in Table 3, that the CI behavior co-occurs mostly with intentions (10 co-occurrences), followed by normative beliefs and norms. The direct association of norms with CI behavior in this Company is evidence that the normative motivations might often drive the CI behavior without necessarily intending to perform it (Table 3 and Figure 2). As an engineer explained with regard to the normative requirements of customers: "...the idea is to make the product work,

\section{Table 2 - Frequencies of each coded construct}

\begin{tabular}{|c|c|c|c|c|}
\hline \multirow{2}{*}{ F/A Model variables } & \multicolumn{3}{|c|}{ Company } & \multirow{2}{*}{ Total } \\
\hline & A & B & C & \\
\hline Attitudes & 64 & 86 & 53 & 203 \\
\hline Behavior (Continuous Improvement) & 30 & 35 & 52 & 117 \\
\hline Behavioral beliefs & 28 & 66 & 28 & 122 \\
\hline Efficacy beliefs & 6 & 9 & 3 & 18 \\
\hline Enviromental constraints & 36 & 1 & 17 & 54 \\
\hline External variables & 0 & 1 & 5 & 6 \\
\hline Intentions & 38 & 47 & 32 & 117 \\
\hline Norms & 47 & 62 & 62 & 171 \\
\hline Normative beliefs & 33 & 35 & 39 & 107 \\
\hline Self-efficacy & 15 & 13 & 6 & 34 \\
\hline Skills & 31 & 44 & 38 & 113 \\
\hline
\end{tabular}


however there are some problems... if you add up all the small problems it becomes a huge problem... and the customer will usually not accept it".

Table 3 shows that attitude, self-efficacy and norm are also often combined with intention when compared with the link between self-efficacy and skills; however, it can be inferred from the fact that the norm is directly related to the CI behavior that behavioral variables might materialize into CI behavior through the intention.

Figure 2 demonstrates graphically what is displayed in Table 3 - the thicker the link, the greater the association. In this case, it can be seen that the CI behavior in Company A depends mainly on the norm, normative beliefs and intentions "...we are dealing with millions of people transported every day, a lot of money... we cannot let two wires stop systems that cost millions of dollars...". The intention, by the way, mediates the effects of all the other main variables of the F/A model.

At Company A, CI also constitutes a part of the R\&D program and is not associated with any rewards scheme, nor were these improvements suggested by each of the project collaborators "... there are RED programs... they will define the directions of our products for the next five years...". The only reward program is a collective one based on global performance and this does not accurately reflect operational performance. Although the reward scheme is motivated by external factors and might not have a significant impact on the organizational performance, its absence might discour-

Table 3 - Co-occurrence and Jaccard similarity coefficients at F/A model's variable at Company A
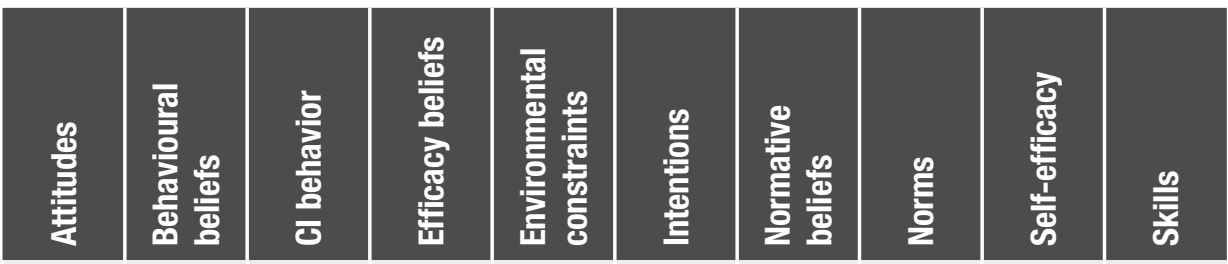

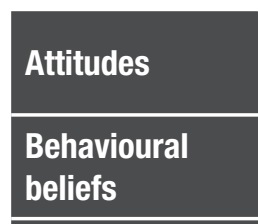

co-ocurrence 70

jaccard coef. $\quad 1$

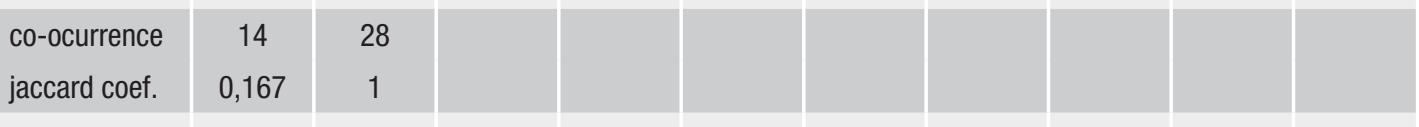

\section{CI behavior}

\section{Efficacy beliefs}

Environmental

constraints

Intentions

Normative

beliefs

\section{Norms}

\section{Self-efficacy}

Skills jaccard co

co-ocurrence 10

jaccard coef

co-ocurrence 20

jaccard coef

co-ocurrence 6

jaccard coef.

co-ocurrence 18

jaccard coef

co-ocurrence 14

jaccard coef.

0,197

co-ocurrence

jaccard coef.

9
0,098

$\begin{array}{lr}\text { co-ocurrence } & 4 \\ \text { jaccard coef. } & 0,056\end{array}$

$10 \quad 3$

$3 \quad 30$

\begin{tabular}{l|l|l|}
0,111 & 0,055 & 1
\end{tabular}

4

056

1

0,03

1

$1 \quad 6$

$0,102 \quad 0,015$

$6 \quad 2$
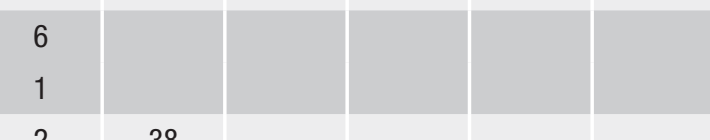

38

\begin{tabular}{|l|l|l|l|}
\hline, 015 & 0,097 & 0,048 & 1 \\
\hline
\end{tabular}

$20 \quad 5$

\begin{tabular}{|r|r|}
\hline & 0,079 \\
\hline & 2
\end{tabular}

\begin{tabular}{c|c|c}
\hline 13 & 3 & 8 \\
0,228 & 0,07 & 0,114 \\
\hline
\end{tabular}

$10 \quad 0$

4

40
1

11

33

\begin{tabular}{|l|l|l}
\hline 0,062 & 0,034 & 0,189 \\
\hline
\end{tabular}

\begin{tabular}{l|l|l|}
0 & 0,06 & 0,177 \\
\hline
\end{tabular}
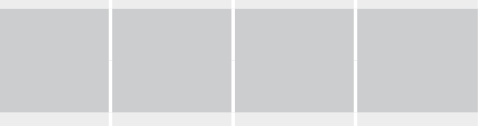

1

\begin{tabular}{|c|c|c|r|}
\hline 6 & 19 & 13 & 4 \\
\hline 0,076 & 0,279 & 0,194 & 1 \\
\hline 2 & 9 & 0 & 4 \\
\hline
\end{tabular}

$\begin{array}{ll}1 & 4\end{array}$

$\begin{array}{ll}4 & 4\end{array}$

2

9

0

4

15

0,024
0
0

0,098
8
0,151

0,235
0
0

5
0,078

0,196
7
0,109

0
5
0,085

0,069
16
0,258

0

\begin{tabular}{c|c|c|}
\hline 16 & 1 & 31 \\
\hline 0,258 & 0,022 & 1 \\
\hline
\end{tabular}




\section{Figure 2 - Relation between $\mathrm{Cl}$ behavior and other constructs at Company $\mathrm{A}$}

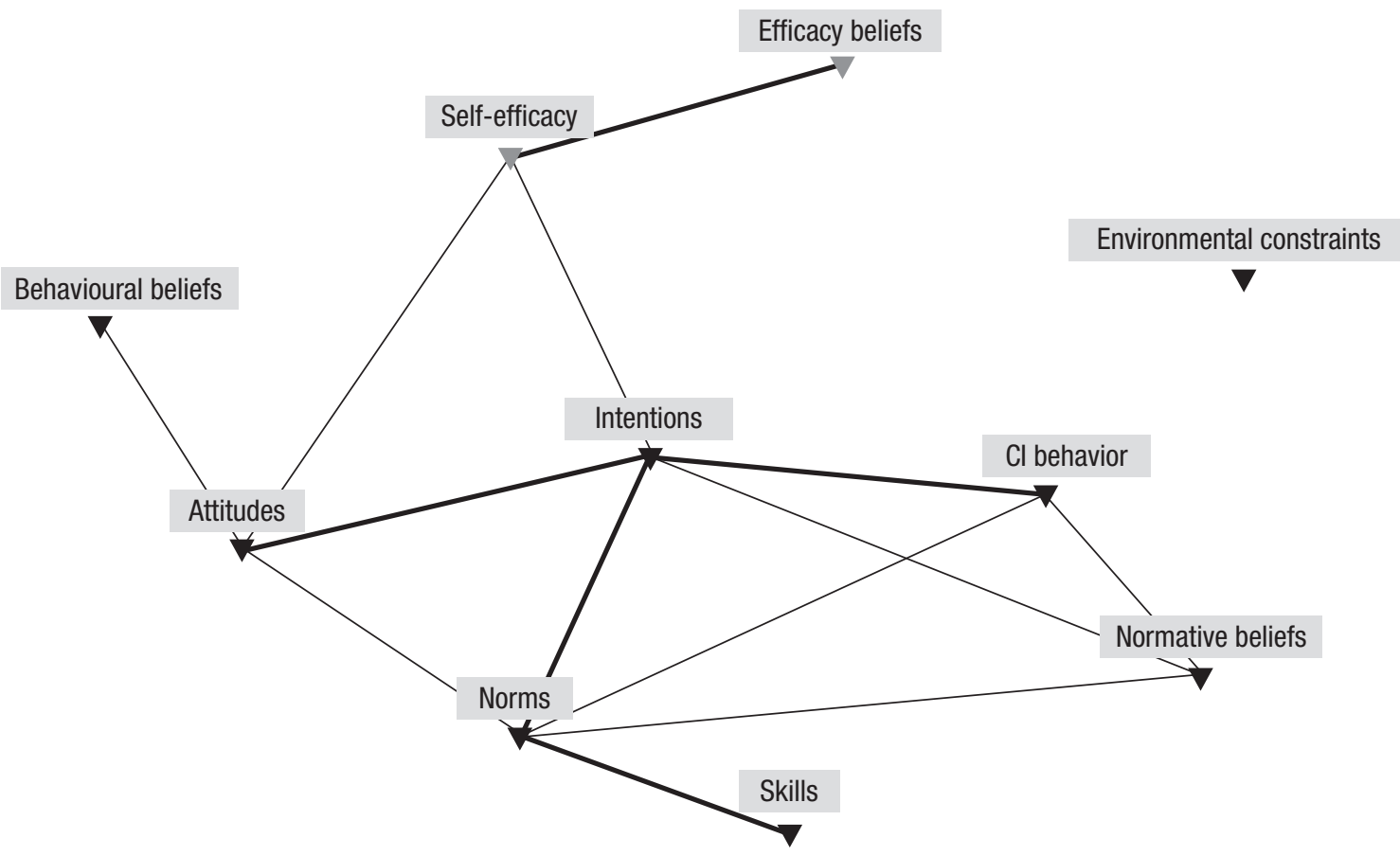

Figure 3 - Relation between $\mathrm{Cl}$ behavior and other constructs at Company $\mathrm{B}$

Enviromental constraints

$\nabla$

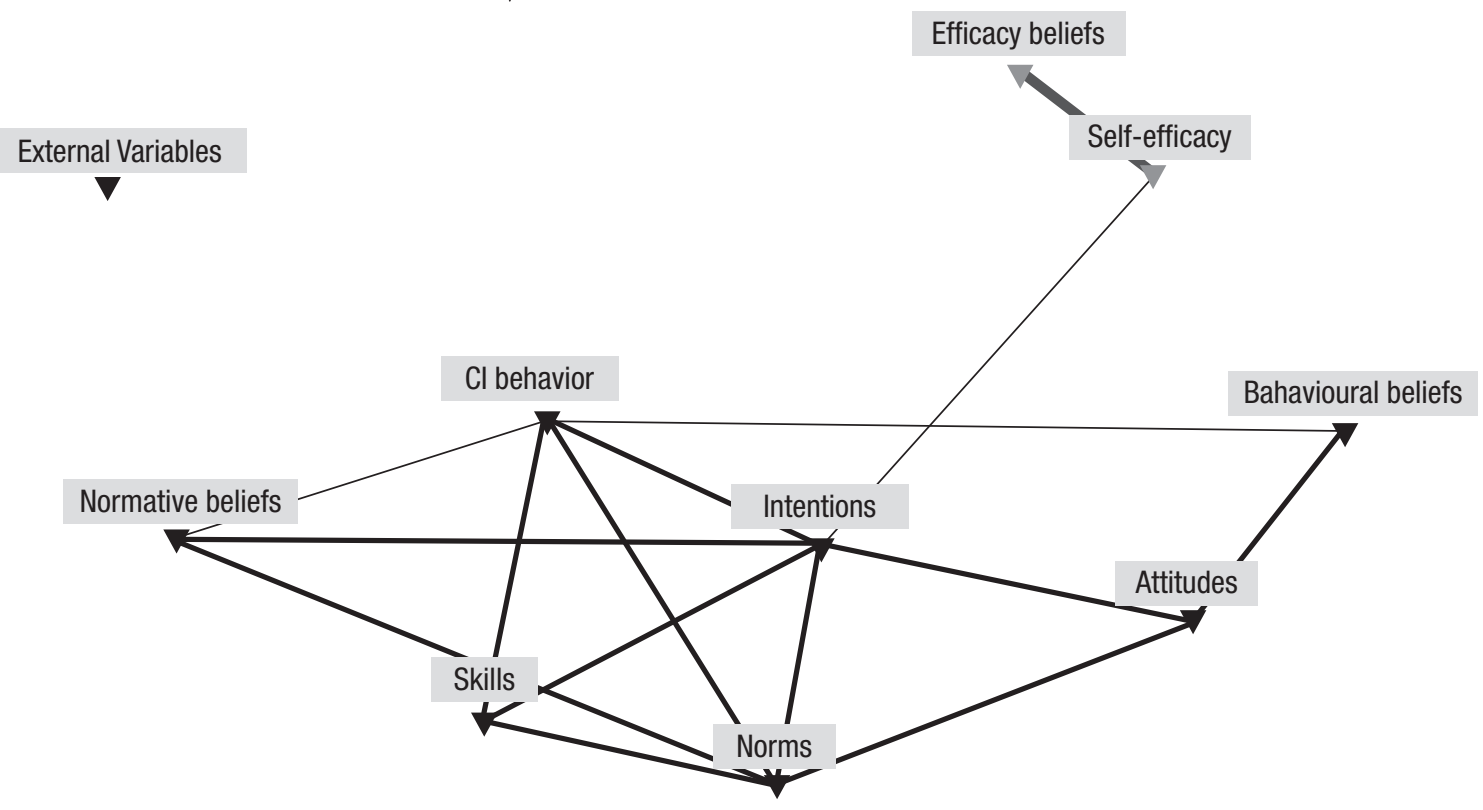


age employees from sharing the established goals of the organizations (AHMAD and SCHROEDER, 2003).

\section{Company B}

At Company B, the organization philosophy was based on participative management. This principle has forged a mentality that involves a long- term relationship, continuous learning (funding for several learning and training sessions), teamwork and job security (despite being seriously affected by the economic crisis of 2008, this company did not reduce its workforce). The top managers seek to increase synergy among the employees and encourage everyone to believe that playing a collective game is better than an individual one (Engineering director: "we don't fire employees... we don't say that you are useless to our company..."; "our company plays soccer and not tennis, so we win together..."). As a result, the employees are eager to participate in the small improvements that can enhance local performance. In terms of numbers, there are, approximately, 189 ideas suggested per employee per year, or one idea every 3 minutes (Table 4 and Figure 3).

From Table 4, it can be observed that the CI behavior co-occurred frequently with skill (19 times),

\section{Table 4 - Co-occurrence and Jaccard similarity coefficients at F/A model's variable at Company B}
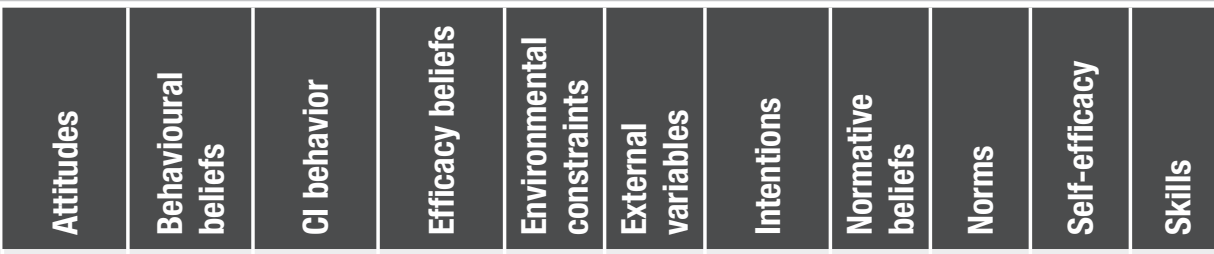

\begin{tabular}{|c|c|c|c|c|c|c|c|c|c|c|c|c|}
\hline Attitudes & $\begin{array}{l}\text { Co-occurence } \\
\text { Jaccard coef. }\end{array}$ & $\begin{array}{c}120 \\
1\end{array}$ & & & & & & & & & & \\
\hline $\begin{array}{l}\text { Behavioural } \\
\text { beliefs }\end{array}$ & $\begin{array}{l}\text { Co-occurence } \\
\text { Jaccard coef. }\end{array}$ & $\begin{array}{c}42 \\
0,288\end{array}$ & $\begin{array}{c}68 \\
1\end{array}$ & & & & & & & & & \\
\hline CI behavior & $\begin{array}{l}\text { Co-occurence } \\
\text { Jaccard coef. }\end{array}$ & $\begin{array}{c}18 \\
0,131\end{array}$ & $\begin{array}{c}14 \\
0,157\end{array}$ & $\begin{array}{c}35 \\
1\end{array}$ & & & & & & & & \\
\hline Efficacy beliefs & $\begin{array}{l}\text { Co-occurence } \\
\text { Jaccard coef. }\end{array}$ & $\begin{array}{c}12 \\
0,103\end{array}$ & $\begin{array}{c}7 \\
0,1\end{array}$ & $\begin{array}{c}2 \\
0,048\end{array}$ & $\begin{array}{l}9 \\
1\end{array}$ & & & & & & & \\
\hline $\begin{array}{l}\text { Environmental } \\
\text { constraints }\end{array}$ & $\begin{array}{l}\text { Co-occurence } \\
\text { Jaccard coef. }\end{array}$ & $\begin{array}{c}1 \\
0,008\end{array}$ & $\begin{array}{l}0 \\
0\end{array}$ & $\begin{array}{l}0 \\
0\end{array}$ & $\begin{array}{l}0 \\
0\end{array}$ & $\begin{array}{l}1 \\
1\end{array}$ & & & & & & \\
\hline $\begin{array}{l}\text { External } \\
\text { variables }\end{array}$ & $\begin{array}{l}\text { Co-occurence } \\
\text { Jaccard coef. }\end{array}$ & $\begin{array}{l}0 \\
0\end{array}$ & $\begin{array}{l}0 \\
0\end{array}$ & $\begin{array}{l}0 \\
0\end{array}$ & $\begin{array}{l}0 \\
0\end{array}$ & $\begin{array}{l}0 \\
0\end{array}$ & $\begin{array}{l}1 \\
1\end{array}$ & & & & & \\
\hline Intentions & $\begin{array}{l}\text { Co-occurence } \\
\text { Jaccard coef. }\end{array}$ & $\begin{array}{c}39 \\
0,305\end{array}$ & $\begin{array}{c}13 \\
0,127\end{array}$ & $\begin{array}{c}19 \\
0,302\end{array}$ & $\begin{array}{c}6 \\
0,12\end{array}$ & $\begin{array}{c}1 \\
0,021\end{array}$ & $\begin{array}{c}1 \\
0,021\end{array}$ & $\begin{array}{c}47 \\
1\end{array}$ & & & & \\
\hline $\begin{array}{l}\text { Normative } \\
\text { beliefs }\end{array}$ & $\begin{array}{l}\text { Co-occurence } \\
\text { Jaccard coef. }\end{array}$ & $\begin{array}{c}18 \\
0,131\end{array}$ & $\begin{array}{c}10 \\
0,108\end{array}$ & $\begin{array}{c}10 \\
0,167\end{array}$ & $\begin{array}{c}1 \\
0,023\end{array}$ & $\begin{array}{l}0 \\
0\end{array}$ & $\begin{array}{l}0 \\
0\end{array}$ & $\begin{array}{c}15 \\
0,224\end{array}$ & $\begin{array}{c}35 \\
1\end{array}$ & & & \\
\hline Norms & $\begin{array}{l}\text { Co-occurence } \\
\text { Jaccard coef. }\end{array}$ & $\begin{array}{c}34 \\
0,227\end{array}$ & $\begin{array}{c}9 \\
0,073\end{array}$ & $\begin{array}{c}17 \\
0,207\end{array}$ & $\begin{array}{c}1 \\
0,014\end{array}$ & $\begin{array}{c}1 \\
0,016\end{array}$ & $\begin{array}{c}1 \\
0,016\end{array}$ & $\begin{array}{c}27 \\
0,321\end{array}$ & $\begin{array}{c}17 \\
0,207\end{array}$ & $\begin{array}{c}64 \\
1\end{array}$ & & \\
\hline Self-efficacy & $\begin{array}{l}\text { Co-occurence } \\
\text { Jaccard coef. }\end{array}$ & $\begin{array}{c}16 \\
0,137\end{array}$ & $\begin{array}{c}7 \\
0,095\end{array}$ & $\begin{array}{c}5 \\
0,116\end{array}$ & $\begin{array}{c}7 \\
0,467\end{array}$ & $\begin{array}{l}0 \\
0\end{array}$ & $\begin{array}{l}0 \\
0\end{array}$ & $\begin{array}{c}9 \\
0,176\end{array}$ & $\begin{array}{c}2 \\
0,043\end{array}$ & $\begin{array}{c}2 \\
0,027\end{array}$ & $\begin{array}{c}13 \\
1\end{array}$ & \\
\hline Skills & $\begin{array}{l}\text { Co-occurence } \\
\text { Jaccard coef. }\end{array}$ & $\begin{array}{c}12 \\
0,078\end{array}$ & $\begin{array}{c}10 \\
0,096\end{array}$ & $\begin{array}{c}19 \\
0,306\end{array}$ & $\begin{array}{c}4 \\
0,078\end{array}$ & $\begin{array}{l}0 \\
0\end{array}$ & $\begin{array}{l}0 \\
0\end{array}$ & $\begin{array}{c}22 \\
0,31\end{array}$ & $\begin{array}{c}5 \\
0,066\end{array}$ & $\begin{array}{c}26 \\
0,31\end{array}$ & $\begin{array}{c}4 \\
0,073\end{array}$ & $\begin{array}{c}46 \\
1\end{array}$ \\
\hline
\end{tabular}


intention (19 times) and Norms (17 times). However, it is less associated with normative beliefs (10 times) or behavioral beliefs. It should be stressed that the direct association between behavioral beliefs and CI behavior might be evidence that the goal of the top managers to establish a participative culture has been achieved.

The pattern of CI behavior in Company B shows that several main antecedents (self-efficacy, attitudes, norms) manifested in the intention to perform the improvement, i.e. attitude causing an intention to improve:"... if you suggest an idea that did not work correctly, another idea automatically arises from a colleague to tackle the problem...". However, the direct association between norms and CI behavior is evidence that, in some situations, CI was performed without the need for the intention to perform it. Well-established norms and standards inside the organization can force the employee to perform an improvement without having a real intention do it, for example, the minimum number of ideas that an employee must suggest in one year "... We monitor how many ideas each employee suggests... We have a target, if you are hired today, your target will be 100 ideas per year...".
On the other hand, common and accepted behavioral beliefs seem to have created an organizational environment that allows the CI goals to be achieved for example, if everybody inside the organization really believes that they are a part of the organization and their contributions are extremely important to achieve the organizational goals. In this case, the organizational goal might be waste reduction, procedural improvements, or any other.

Displaying the information of Table 4 in a graphical form, Figure 3 demonstrates that the CI behavior is directly influenced by normative and behavioral beliefs, skills, norms and intentions, although the intention plays the role of a mediator for the other variables such as attitudes and self-efficacy.

In Company $\mathrm{B}$, in qualitative terms, a part of the relation between intention and CI behavior can be attributed to concepts mentioned by Ahmad and Schroeder (2003), where employment security is a means of obtaining employee loyalty and boosting motivation, while at the same time gearing employees toward competitive organizational goals, in this case, a longterm relationship, innovativeness and continuous improvement.

\section{Figure 4 - Relation between $\mathrm{Cl}$ behavior and other constructs at the Company $\mathrm{C}$}
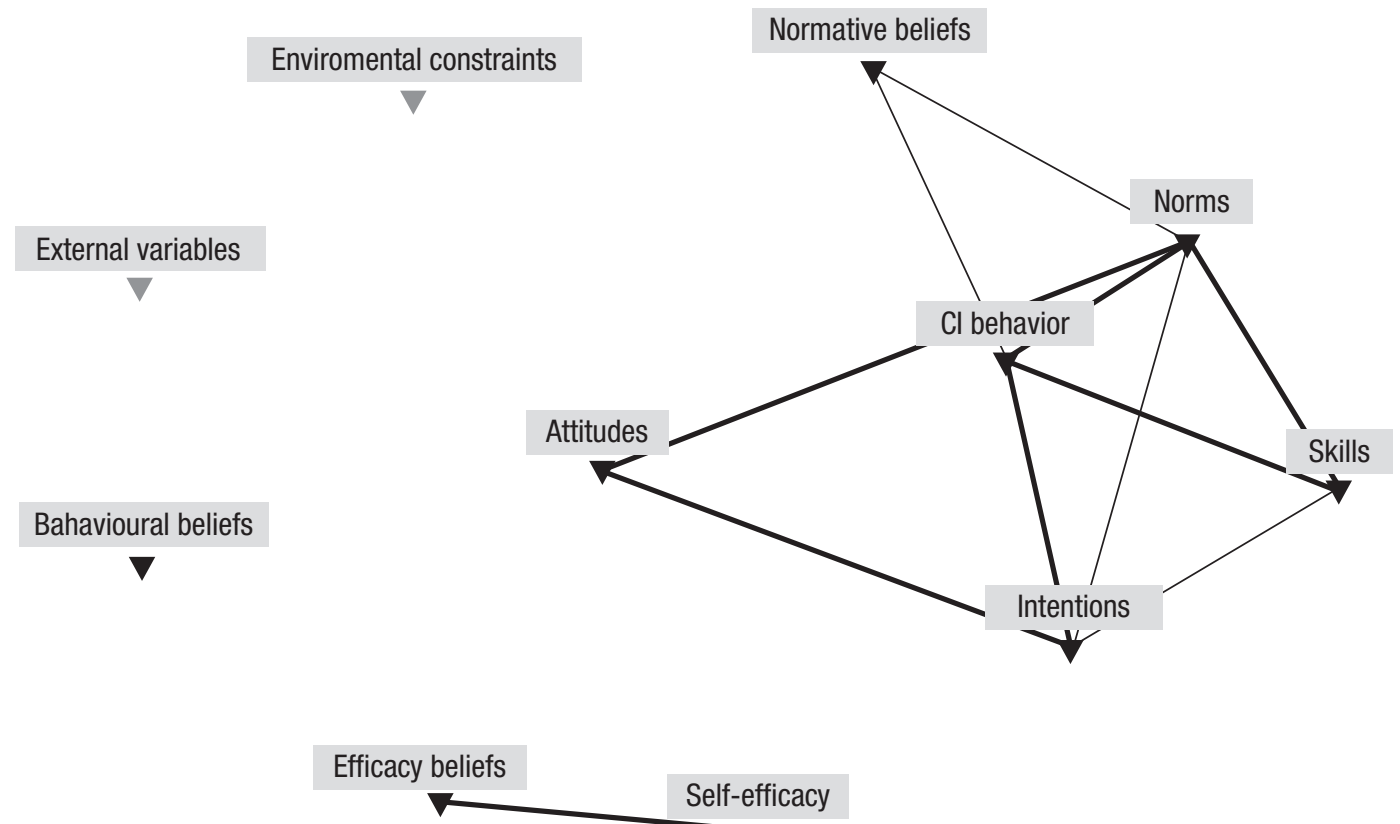
Apart from the question of intention, the result of Company $\mathrm{B}$, once again strengthens the notion that normative factors can also influence CI behavior. This result was expected because some improvements are not necessarily proactive, but imposed by customers and market requirements, such as for example, the introduction of the concept of overall equipment effectiveness "... once a year our customers come to our company to present their ideas concerning cans and also discuss what they expect...".

Together with normative and behavioral beliefs and intentions, there are several factors that have cooccurred with CI behavior, such as skills and norms. This co-occurrence has been explained by several earlier studies that have demonstrated that the intention might not be the only determinant of individual behavior (DAVIS, 1985; Jo and others, 2003). The belief that the intention plays the role of a mediator in the $\mathrm{F} / \mathrm{A}$ model is challenged by the present research when it is applied in an Operational Management context.

Another notable point in Company B is the attitude to continuous learning. This attitude according to Ni \& Sun (2009), Anand and others (2009) and Bessant and others (2001), is indispensable for the CI capability as well for the organizational performance (Ahmad and Schroeder, 2003). In this company, knowledge sharing was greatly encouraged and widely practiced through the idea suggestion system. This system is a kind of information database with implemented ideas and everybody can use it to look for ideas through the problem-solving process "...ideas sent are recorded in our database... and it works as a mini google...". This system motivates the employees and offers them opportunities to make improvements and then participate in the knowledge sharing (SIEMSEN and others, 2008).

In summary, the CI behavior at this company was also manifested by the intention to improve the performance and was based on a long- term perspective involving innovativeness and continuous improvement

\footnotetext{
"...our employees are considered inventors..."; "... most of the ideas are simple... we don't mind if the idea suggested doesn't work, if it doesn't work, it doesn't work, making a mistake is a part of the game...we don't obstruct ideas, - actually, we encourage ideas to make people get used to what is new...
}

This intention was driven by normative impositions such as customer requirements and standards, learning attitudes and a willingness to keep improving, as can be seen in the interview referred to above.

\section{Company C}

At Company C, the CI behavior is largely governed by normative considerations (Table 5 and Figure 4). These factors are all related to customer requirements, certifications and audits. These normative motivations gave rise to several CI procedures and toolkits, such as $8 \mathrm{D}$, FEMEA, CI project teams.

The toolkits, CI programs and procedures gave rise to well-developed technical skills, which the CI behavior relies on. However, in this case, it is possible to find out the direct link between Norms and attitudes. This relation is not present in the F/A model (FISHBEIN, 2000), but according to the interviews, the constant audits have resulted in a learning attitude, and are manifested in the intention to perform continuous improvement. To start with, this attitude was not pro-active; although, with the growth of the company, employees began to understand the importance of quality; then they became increasingly participative in terms of their willingness to perform continuous improvement (Figure 4). As one of the managers pointed out: "... the main way the customer interferes with us is through the audits... we intended to supply goods to a big truck company, then we were audited and trained..."

These combinations of $\mathrm{CI}$ behavior, intentions and normative motivations (Table 5 and Figure 4) has demonstrated that the managers manifested a willingness to improve However, this willingness was in many cases, supported by normative motivations, since this company is an automobile supplier "...the requirements come from the customer, and are increasingly more demanding ...but all of them are treated... then each year in January, we all sit together and set our target rates higher (reducing the waste by 10\% each year)...". The stringent conditions of this industry forced Company C to comply strictly with international quality standards, product design documentation and rigid product quality control procedures. In this situation, the normative motivations bypass the intention; for instance, the company might be forced to spend more resources on changing an alloy composition for the foundry when required by the customer.

According to the interviews, several improvements were motivated by the customer's audits. The influence exerted by these constant normative impositions on 
improving behavior can be regarded as evidence of a direct link between normative procedures and behavior. This reinforces the fact that the norms are given priority over the intentions, once more challenging the F/A model.

\section{Overview}

When the three cases are analyzed together, there is evidence that, in the first place, the CI behavior is closely bound up with intention, norms and skills (Table 6 and Figure 5), and is then followed by the attitudes and behavioral beliefs that are needed to improve continuously. This result challenges the value of the F/A model where only the intention precedes behavior, since the evidence has demonstrated that it might be just one of the mediator constructs. Thus, the first proposition was partially supported.

These findings also suggest that the relations between the variables in the F/A model might be influenced by contingency variables such as competitive industrial pressure and an organizational strategy definition (SOUZA and VOSS, 2008). In this case, the contextual and organizational variables create new

Table 5 - Co-occurrence and Jaccard similarity coefficients at F/A model's variable at Company C

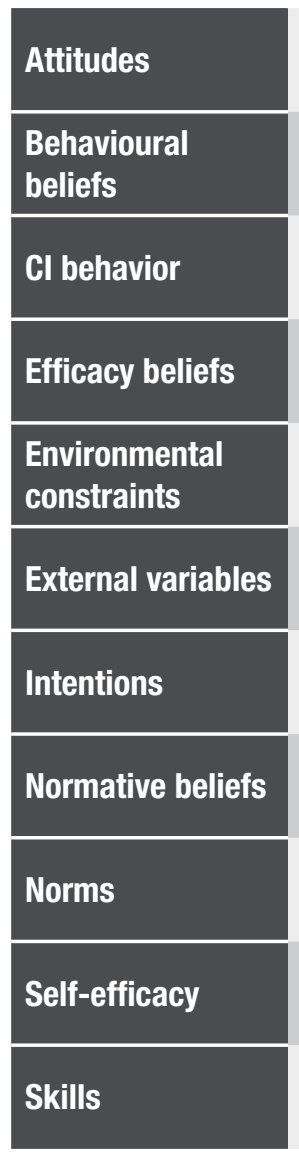

Co-occurence Jaccard coef. Co-occurence Jaccard coef. Co-occurence Jaccard coef. Co-occurence Jaccard coef. Co-occurence Jaccard coef. Co-occurence Jaccard coef. Co-occurence Jaccard coef. Co-occurence Jaccard coef. Co-occurence Jaccard coef. Co-occurence Jaccard coef. Co-occurence Jaccard coef.
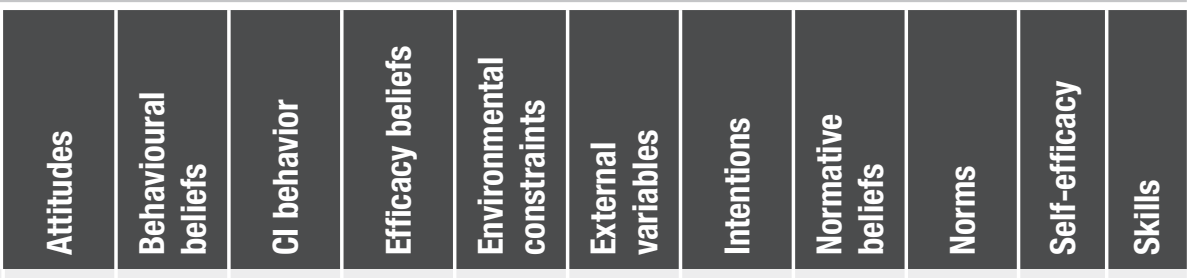

61
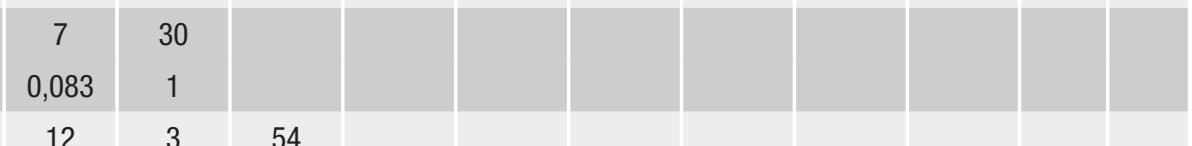

$$
\begin{array}{|l|l|l|}
0,117 & 0,037 & 1 \\
\hline
\end{array}
$$

\begin{tabular}{|c|c|c|c|c|c|}
\hline 0 & 1 & 0 & 3 \\
\hline 0 & 0,031 & 0 & 1 & \\
\hline 1 & 1 & 3 & 0 & 17 \\
\hline
\end{tabular}
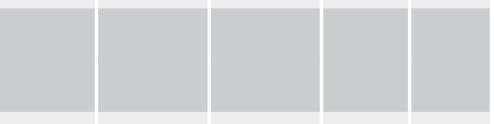

\begin{tabular}{l|l|l|l|l|l|l|l}
1 & 3 & 0 & 17 & \\
0,013 & 0,022 & 0,044 & 0 & 1
\end{tabular}

\begin{tabular}{|c|c|c|c|c|c|c|}
\hline 0,013 & 0,022 & 0,044 & 0 & 1 & \\
\hline 2 & 0 & 1 & 0 & 1 & 5 \\
0,031 & 0 & 0,017 & 0 & 0,048 & 1 \\
\hline
\end{tabular}

32

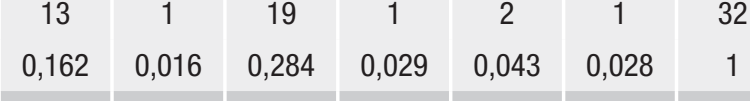

\begin{tabular}{|c|c|c|c|c|c|c|c|c|c|c|}
\hline 3 & 0 & 13 & 0 & 0 & 0 & 6 & 41 \\
\hline 0,03 & 0 & 0,159 & 0 & 0 & 0 & 0,09 & 1 \\
\hline
\end{tabular}

\begin{tabular}{|c|c|c|c|c|c|c|c|c|c|c|}
\hline 18 & 0 & 28 & 0 & 2 & 1 & 11 & 13 & 62 & & \\
\hline 0,171 & 0 & 0,318 & 0 & 0,026 & 0,015 & 0,133 & 0,144 & 1 & & \\
\hline 5 & 1 & 1 & 2 & 0 & 0 & 4 & 0 & 0 & 6 & \\
\hline 0,081 & 0,029 & 0,017 & 0,286 & 0 & 0 & 0,118 & 0 & 0 & 1 & \\
\hline 9 & 2 & 16 & 0 & 0 & 0 & 10 & 4 & 21 & 0 & 44 \\
\hline 0,094 & 0,028 & 0,195 & 0 & 0 & 0 & 0,152 & 0,049 & 0,247 & 0 & 1 \\
\hline
\end{tabular}


relations within the F/A model which might not be strong or important enough while analyzing a person individually from a psychological perspective, as proposed by the original model.

From an organizational perspective, the behavior of the model, very often takes into account the interests of the stakeholder involved, such as shareholders, society, government, employees, suppliers and customers. These players usually have different interests and establish different ways of molding organizational behavior. For example, the government can enforce behavior by legislation; alternatively, the way the shareholders require a financial return on their investment also determines whether the organization will focus on long or short- term operational behavior. However, throughout the interviews, it could be inferred that the causal relationship between the subjective beliefs and norms, attitudes and self-efficacy supported propositions 2 and 3 .

If this model is analyzed through OM theories, the balance between exploration and exploitation, as suggested by Benner and Tushman (BENNER and TUSHMAN, 2003), also supports the contingency and dependency of the F/A model. According to these authors, exploitation is related to incremental and continuous improvement procedures and is based on rigid norma- tive processes such as Six sigma or TQM. Hence, it was not surprising to find in this research that there was a close relationship between CI behavior, skills (toolkits and processes) and normative motivations.

To summarize, the intention to perform the behavior can be overridden by normative factors in an organizational context and the F/A model can be contingent and dependent.

Finally, despite the contingency variables, it is still worth highlighting the fact that intentions, attitudes and behavioral beliefs played an important role in sustaining the CI behavior, because the lasting CI types of behavior were more evident at Company B and C where the CI behavioral beliefs were fully assimilated by the employees. In addition, the self-efficacy beliefs fostered a willingness to improve, like in Company B, where all the employees had a strong willingness to learn and were self-confident about their ability to suggest ideas for improvement.

\section{FINAL CONSIDERATIONS}

A literature review was carried out in this paper concerning $\mathrm{CI}$ in Operations Management, and the

\section{Figure 5 - Relation between $\mathrm{Cl}$ behavior and other constructs}

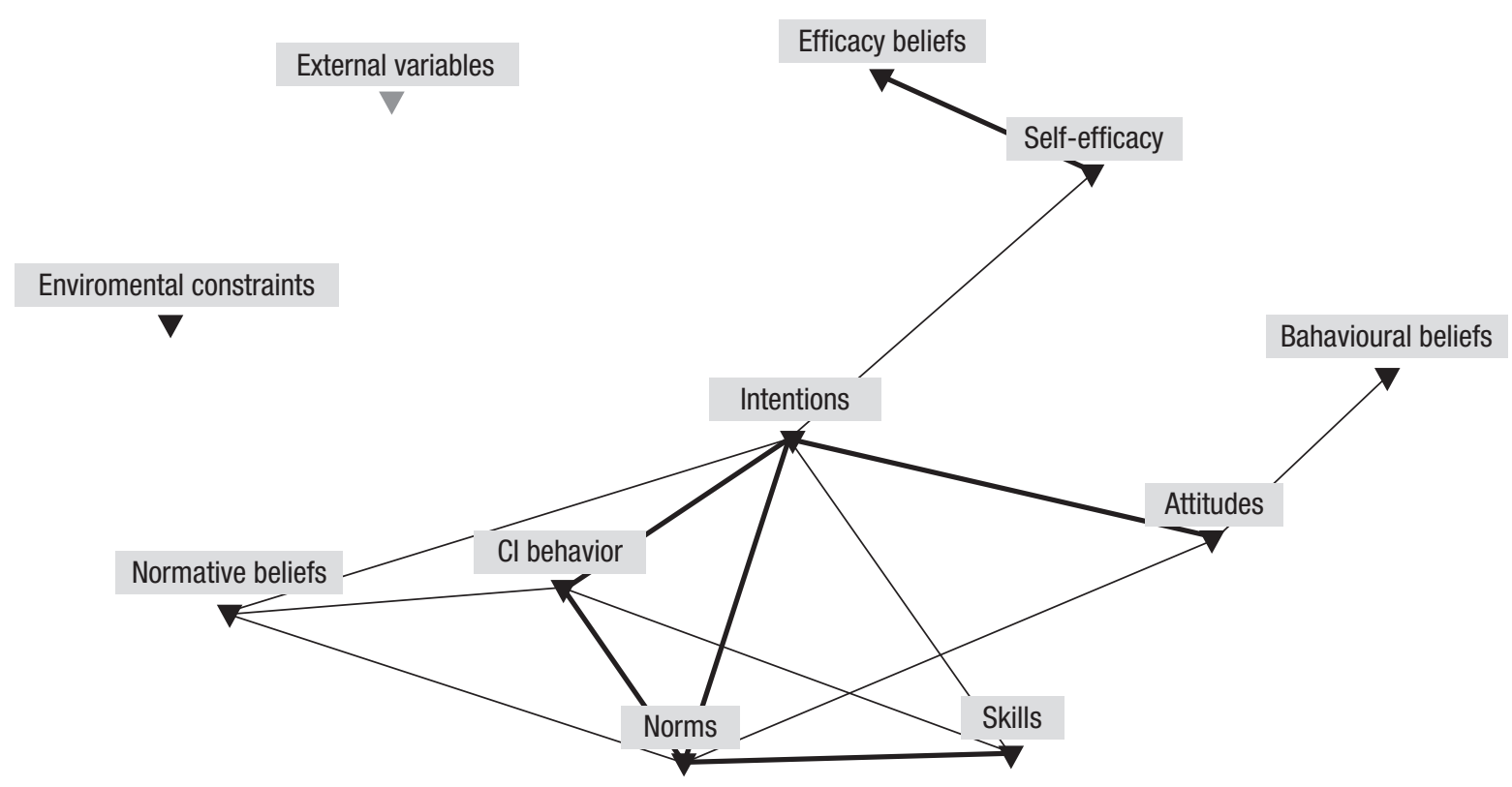


CI capability was discussed from the perspective of RBV. Following this, there was an investigation of the Theory of Reasoned Action of Fishbein and Ajzen (FISHBEIN, 2000; FISHBEIN and AJZEN, 1975), which was applied to analyze the CI capability. This analysis adopted CI capability as a bundle of Operational routines which are the way people act or behave and solve problems in an organization. (BESSANT and FRANCIS, 1999; PENG, and others, 2008).

In empirical terms, this research employed a multicase study and the data were collected by conducting semi-structured interviews and paying technical visits.
The interviews were recorded, transcribed and coded according to the F/A model and QDA Miner qualitative research software was employed to support the coding and compilation of results.

This paper found that with the CI capability, the intentions to perform CI behavior can be overridden by normative motivations and the intention itself might not be the only predictor, nor does it mediate all the other variables to execute a type of behavior. This finding supports previous studies such as Bendoly and others (2006), Davis (1985), Jo and others (2003), Schwenk and Mosser (2008), although, apart from Bendoly and

Table 6 - Overall co-occurrence and Jaccard similarity coefficients at F/A model's variable
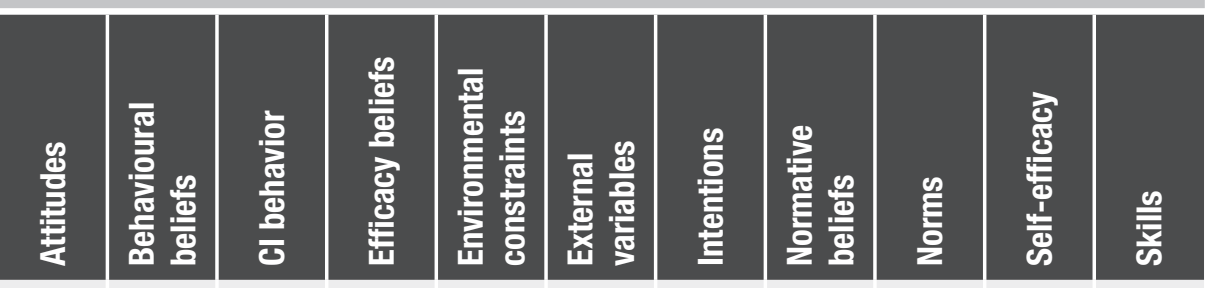

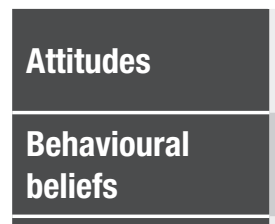

Cl behavior

\section{Efficacy beliefs}

Environmental constraints

External
variables

Intentions

Normative

beliefs

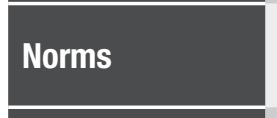

Self-efficacy

Skills

\section{Co-occurence 251}

Jaccard coef. 1

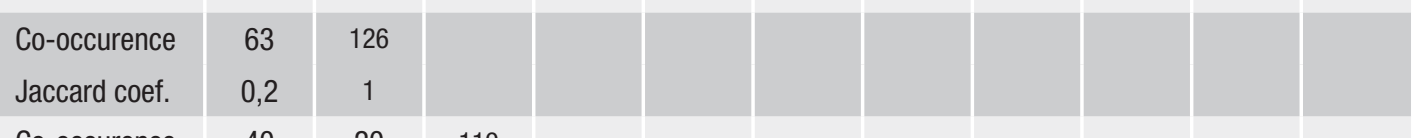

\begin{tabular}{|l|l|l|l|}
\hline Co-occurence & 40 & 20 & 119 \\
\hline
\end{tabular}

\begin{tabular}{|l|l|l|l|}
\hline Jaccard coef. & 0,12 & 0,09 & 1 \\
\hline
\end{tabular}

\begin{tabular}{|c|c|c|c|c|c|c|c|c|c|c|c|c|c|}
\hline Co-occurence & 16 & 9 & 3 & 18 \\
Jaccard coef. & 0,06 & 0,07 & 0,02 & 1 \\
\hline
\end{tabular}

\begin{tabular}{|l|l|l|l|l|l|}
\hline Co-occurence & 12 & 2 & 9 & 2 & 56 \\
\hline
\end{tabular}

\begin{tabular}{|c|c|c|c|c|c|} 
Jaccard coef. & 0,04 & 0,01 & 0,05 & 0,03 & 1 \\
\hline
\end{tabular}

\begin{tabular}{l|c|c|c|c|c|c|c|c|c|c|c|} 
Co-occurence & 2 & 0 & 1 & 0 & 1 & 6 \\
Jaccard coef. & 0,01 & 0 & 0,01 & 0 & 0,02 & 1 & \\
\hline
\end{tabular}

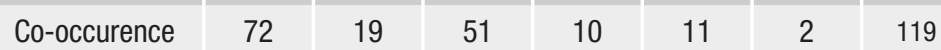

\begin{tabular}{|l|l|l|l|l|l|l|l|} 
Jaccard coef. & 0,24 & 0,08 & 0,27 & 0,08 & 0,07 & 0,02 & 1 \\
\hline
\end{tabular}

\begin{tabular}{|l|l|l|l|l|l|l|l|l|}
\hline Co-occurence & 27 & 12 & 33 & 1 & 4 & 0 & 32 \\
\hline
\end{tabular}

\begin{tabular}{|c|c|c|c|c|c|c|c|} 
Jaccard coef. & 0,08 & 0,05 & 0,17 & 0,01 & 0,03 & 0 & 0,16 \\
\hline
\end{tabular}

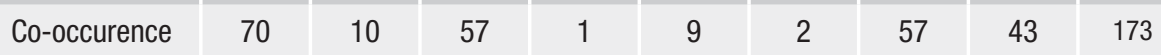

\begin{tabular}{|l|l|l|l|l|l|l|l|l|l|} 
Jaccard coef. & 0,2 & 0,04 & 0,24 & 0,01 & 0,04 & 0,01 & 0,24 & 0,18 & 1 \\
\hline
\end{tabular}

\begin{tabular}{|l|l|l|l|l|l|l|l|l|l|l|}
\hline Co-occurence & 35 & 9 & 10 & 13 & 2 & 0 & 22 & 2 & 6 & 34 \\
\hline
\end{tabular}

\begin{tabular}{l|l|l|l|l|l|l} 
Jaccard coef. & 0,14 & 0,06 & 0,07 & 0,33 & 0,02 \\
\hline
\end{tabular}

\begin{tabular}{|l|l|l|l|l|l|l|l|l|}
\hline Co-occurence & 30 & 12 & 43 & 4 & 5 & 0 & 39 \\
\hline
\end{tabular}

\begin{tabular}{|l|l|l|l|l|l|} 
Jaccard coef. & 0,09 & 0,05 & 0,22 & 0,03 & 0,03 \\
\hline
\end{tabular}

\begin{tabular}{l|l|l|l}
39 & 14 & 63
\end{tabular}

0,19

0,0

๑RAE || São Paulo | 
others (2006), this earlier research was not undertaken in the context of OM.

The main contribution made by this paper was to introduce the F/A model to analyze corporate phenomena in OM. As a result, this research suggests that the $\mathrm{F} / \mathrm{A}$ model can be extremely useful in research in an Operations context as well as its already proven importance in health, psychology and marketing. However, it needs to be adjusted to deal with some organizational and Operational variables so that it can be more suited to OM research.

The suggestions for improvements should take account of organizational variables and mindsets that can be assumed to exist in the model, such as Groupthink/ Abilene paradox or blaming attitudes (BENDOLY and others, 2010). Formerly this model was extensively used to predict and understand individual behavior; however, an organization involves not one, but sometime hundreds or thousands of people.

In addition, the strategic priority defines the nature of the capability that must be developed or the balance of exploitation and exploration (BENNER and TUSHMAN, 2003). In view of this, the way the variables of the $\mathrm{F} / \mathrm{A}$ models are interrelated might also vary according to the type of capability involved. In the case of the CI capability which is based on standardized, rigid procedures and toolkits, its behavior might be strongly influenced by the normative beliefs and motivations. Nonetheless, the lasting CI behavior might be supported by common and assimilated values that everyone in the organization can add to with small and creative ideas and thus make a local improvement to the organizational performance (BESSANT, and others, 2001; BESSANT, and others, 1994; SCHROEDER and ROBINSON, 1991).

The limitations of this research are those intrinsic to studies that rely on qualitative methods and a restricted number of sample cases. In future research, we recommend testing this model empirically in the context of the Operation and also to take into account the influence of contingency variables such as strategy definition, industry, country or the growth of the company (SOUSA and VOSS, 2001, 2008). This paper also suggests exploring the innovation capability based on this model (because it should be less normative) and then comparing it to the results of the present study.

\section{REFERENCES}

ADLER, P. S, BENNER, M, BRUNNER, D. J, MACDUFFIE, J.
P, OSONO, E, STAATS, B. R. Perspectives on the productivity dilemma. Journal of Operations Management, v. 27, n. 2, p. 99-113, 2009.

AHMAD, S, \& SCHROEDER, R. G. The impact of human resource management practices on operational performance: recognizing country and industry differences. Journal of Operations Management, v. 2, n. 1, p. 19-43, 2003.

ANAND, G, WARD, P. T, TATIKONDA, M, \& SCHILLING, D. A. Dynamic capabilities through continuous improvement infrastructure. Journal of Operations Management, v. 27, n. 6, p. 444-461, 2009.

BARNEY, J. B. Firm Resources and Sustained Competitive Advantage. Journal of Management, $v$. 17, n. 1, p. 99-120, 1991.

BENDOLY, E, CROSON, R, GONCALVES, P, \& SCHULTZ, K. Bodies of Knowledge for Research in Behavioral Operations. Production and Operations Management, v.19, $\mathrm{n}$. 4, p. 434-452, 2010.

BENDOLY, E, DONOHUE, K, \& SCHULTZ, K. L. Behavior in operations management: Assessing recent findings and revisiting old assumptions. Journal of Operations Management, v. 24, n. 6, p. 737-752, 2006.

BENNER, M. J, \& TUSHMAN, M. L. Exploitation, Exploration and Process Management: The Productivity Dilemma Revisited. Academy of Management Review, v. 28, n. 2, p. 20, 2003.

BERGER, A. Continuous improvement and Kaizen: standardization and organizational designs. Integrated Manufacturing Systems, v. 8, n. 2, p. 7, 1997.

BESSANT, J, \& CAFFYN, S. High-involvement innovation through continuous improvement. International Journal of Technology Management, v. 14, n.1, p. 7-28, 1997.

BESSANT, J, CAFFYN, S, \& GALLAGHER, M. An evolutionary model of continuous improvement behaviour. Technovation, v. 21, n. 2, p. 67-77, 2001.

BESSANT, J, CAFFYN, S, GILBERT, J, HARDING, R, \& WEBB, S. Rediscovering Continuous Improvement. Technovation, v.14, n. 1, p. 17-29, 1994.

BESSANT, J, \& FRANCIS, D. Developing strategic continuous improvement capability. International Journal of 
Operations \& Production Management, v. 19, n. 11, p. 1106-1119, 1999.

BOUDREAU, J, HOPP, W, MCCLAIN, J. O, \& THOMAS, L. J. Commissioned Paper: On the Interface Between Operations and Human Resources Management. Manufacturing. Service Operations Management, v. 5, n. 3, p. 179-202, 2003.

CAFFYN, S. Development of a continuous improvement self-assessment tool. International Journal of Operations $\mathcal{E}$ Production Management, v. 19, n. 11, p. 16, 1999.

CHAN, R. Y.-K, \& LAU, L. A test of the Fishbein-Ajzen behavioral intentions model under Chinese cultural settings: are there any differences between PRC and Hong Kong consumers?". Journal of Marketing Practice: Applied Marketing Science, v. 4, n.4, 1998.

CHOI, T. Conceptualizing continuous improvement: Implications for organizational change. Omega, v. 23, n. 6, p. 607-624, 1995.

CROSON, R. \& DONOHUE, K. Behavioral Causes of the Bullwhip Effect and the Observed Value of Inventory Information. Management Science, v. 52, n. 3, p. 323336, 2006.

DAVIS, R. A. Social Structure, Belief, Attitude, Intention, and Behavior: A Partial Test of Liska's Revisions. Social Psychology Quarterly, v. 48, n. 1, p. 89-93, 1985.

EISENHARDT, K. M. Building Theories from Case Studies Research. Academy of Management Review, v. 14, n. 4, p. 532-550, 1989.

FISHBEIN, M, \& AJZEN, I. Belief, attitude, intention and behavior: an introduction to theory and research. Reading, MA: Addison-Wesley, 1975.

FISHBEIN, M, MIDDlESTADT, S, \& HITCHCOOCK, P. Using information to change sexually: an analysis based on the theory of reasoned action. In J. WASSERHEIT, S. ARAL, \& K.K.HOLMES, Research issues in buman behavior and sexually transmitted diseases in the AIDS era (p. 243-257). Washington, DC: American Society for Microbiology, 1991.

FISHBEIN, M. The role of theory in HIV prevention. Aids Care-Psychological and Socio-Medical Aspects of Aids/Hiv, v. 12, n. 3, p. 273-278, 2000.
FISHBEIN, M, \& AJZEN, I. Belief, Attitude, Intention, and Behavior: An Introduction to Theory and Research: Addison-Wesley, 1975.

FROEHLE, C. M, \& ROTH, A. V. New measurement scales for evaluating perceptions of the technology-mediated customer service experience. Journal of Operations Management, v. 22, n. 1, p. 1-21, 2004.

GINO, F, \& PISANO, G. Toward a Theory of Behavioral Operations. Manufacturing \& Service Operations Management, v. 10, n. 4, p. 676-691, 2008.

ISOBE, T, MAKINO, S, \& MONTGOMERY, D. B. Technological capabilities and firm performance: The case of small manufacturing firms in Japan. Asia Pacific Journal of Management, v. 25, n. 3, p. 413-428, 2008.

JHA, S., MICHELA, J. L, \& NOORI, H. The dynamics of continuous improvement. International Journal of Quality Science, v. 1, n. 1, 1996.

JENSEN, M. B., \& VINDING, A. L. The application of latent class analysis on the measurement of human resource. Introduction. Business, p. 1-19, 2003.

KRIPPENDORF, K. Content Analysis: An Introduction to its Methodology . 2ed. Thousand Oaks: Sage Publications, Inc, 2004.

LEWIS, M. Iterative triangulation: a theory develpment process using evidence case sutdies. Journal Operations Management, v. 16, p. 455-469, 1998.

MATTOS, L. C. L. P. Análise de entrevistas não estruturadas: da formalização à pragmática da linguagem. IN: Pesquisa qualitativa em estudos organizacionais: paradigmas, estratégias e métodos. 2ª .ed. São Paulo: Saraiva, p. 347-373, 2010.

MENEZES, L. M. DE, WOOD, S, \& GELADE, G. The integration of human resource and operation management practices and its link with performance: A longitudinal latent class study. Journal of Operations Management, v. 28, p. 455-471, 2010.

MEREDITH, J. Building operations management theory through case and field research. Journal Operations Management, v. 16, p. 441-454, 1998.

MILES, M. B, \& Huberman, A. M. Qualitative data analysis. 2 ed. Sage Publications, 1994. 
NI, W., \& SUN, H. The relationship among organisational learning, continuous improvement and performance improvement: An evolutionary perspective. Total Quality Management \& Business Excellence, v. 20, n. 10, p. 10411054, 2009.

PAY, R. Everybody's jumping on the lean bandwagon, but many are being taken for a ride. Industrial Week (March 05), 2008.

PENG, D. X, SCHROEDER, R. G, \& SHAH, R. Linking routines to operations capabilities: A new perspective. Journal of Operations Management, v. 26, n. 6, p. 730-748, 2008.

POWELL, T. C. TQM As Competitive Advantage. Strategic Management Journal, v. 16, n.1, p. 24, 1995.

RAHMAN, S.-U. The Future of TQM is Past. Can TQM be Resurrected? Total Quality Management \& Business Excellence, v. 15, n. 4, p. 411-422, 2004.

RUSSELL, W. C. Human assets and management dilemmas: coping with hazards on the road to resource-based theory. Academy of Management Review, v. 22, n. 2, p. 374-402, 1997.

SAVOLAINEN, T. I. Cycles of continuous improvement. International Journal of Operations \& Production Management, v. 19, n. 11, p. 1203-1222, 1999.

SCHROEDER, D. M, \& ROBINSON, A. G. America Most Successful Export to Japan - Continuous Improvement Programs. Sloan Management Review, v. 32, n. 3, p. 67-81, 1991.

SEURING, S. A. Assessing the rigor of case study research in supply chain management. Supply Chain Management: An International Journal, v. 13, n. 2, p. 128-137, 1998.

SILA, I. Examining the effects of contextual factors on TQM and performance through the lens of organizational theories: an empirical study. Journal of Operations Management, v. 1, p. 83-109, 2007.

SCHWENK, G, \& MÖSER, G. Intention and behavior: a Bayesian meta-analysis with focus on the Ajzen-Fishbein Model in the field of environmental behavior. Quality Eamp; Quantity, v. 43, n. 5, p. 743-755, 2009.

SIEMSEN, E, ROTH, A. V, \& BALASUBRAMANIAN, S. How motivation, opportunity, and ability drive knowledge sha- ring: The constraining-factor model. Journal of Operations Management, v. 26, n. 3, p. 426-445, 2008.

SOUSA, R., \& VOSS, C. A. Quality management: universal or context dependent? Production and Operations Management, v. 10, n. 4, p. 383-404, 2001.

SOUSA, R., \& VOSS, C. A. Contingency research in operations management practices. Journal of Operations Management, v. 26, n. 6, p. 697-713, 2008.

STRASSER, A. A, CAPPELLA, J. N, JEPSON, C, FISHBEIN, M, TANG, K. Z, HAN, E, Experimental evaluation of antitobacco PSAs: Effects of message content and format on physiological and behavioral outcomes. Nicotine $\&$ Tobacco Research, v. 11, n. 3, p. 293-302, 2009.

TEECE, D. J, PISANO, G, \& SHUEN, A. Dynamic Capabilities and Strategic Management Strategic Management Journal, v. 18, n. 7 , p. $25,1997$.

WOOD, S. Human Resource Management Performance. International Journal of Management Reviews, v. 4, p. 367-403, 1999.

YZER, M. The Impact of the Work of Martin Fishbein on Health Issues in the World. Health Communication, v. 25, n. $6 / 7$, p. $625-627,2010$. 